\title{
Pancasila as A Basis For Nation's Character Education
}

\author{
Machful Indra Kurniawan \\ Fakultas Ilmu Keguruan dan Ilmu Pendidikan \\ Muhammadiyah University of Sidoarjo \\ Sidoarjo, Indonesia \\ machful.indra.k@gmail.com
}

\begin{abstract}
Character education is an attempt to build the character of the Indonesian nation based on the values of Pancasila. Pancasila is the whole view, ideals and beliefs of the Indonesian nation. Pancasila as an ideology is established from the spiritual, moral, and cultural wealth of Indonesian society and comes from the nation's view of life. Therefore, Pancasila should be used as a guide for Indonesian nation's life. Furthermore, nation's character education must be built based on Pancasila, not other sources such as Religion, Culture, and goal of National Education because Religion, Culture and goal of National education are part of Pancasila.
\end{abstract}

Keywords - pancasila; education character; national education

\section{INTRODUCTION}

To educate the life of all nations is one of goals owned by Indonesian nation as stated in the preamble of Indonesia in 1945 , on the fourth paragraph that states " to form a government of the state of Indonesia which shall protect all the people of Indonesia and all the independence and the land that has been struggled for, and to improve public welfare, to educate the life of the people and to participate toward the establishment of a world order based on freedom, perpetual peace and social justice, therefore the independence of Indonesia shall be formulated into a constitution of the Republic of Indonesia which shall be built into a sovereign state based on a belief in the One and Only God, just and civilized humanity, the unity of Indonesia, and democratic life led by wisdom of thoughts in deliberation amongst representatives of the people, and achieving social justice for all the people of Indonesia. ". Based on the fourth paragraph of the 1945 Constitution, the purpose of the Indonesian nation are; (1) to improve public welfare, (2) to educate the life of the people. (3) to participate toward the establishment of a world order.

Many kinds of laws made by the government are to embody the goal of Indonesian people, especially in educating the people or nation. Regulation in educating life of the nation as written in the law no. 4 in the Year of 1950 and, No. 12 in the Year of 1954 on the basics of education and teaching at schools in Indonesia, Law No. 24 in the Year of 1989 on the national education system, and Law no. 204 in the Year of 2003 on the national education system.

Referred to the goals of national education system, it reveals that character education based on the values of
Pancasila is one of goals to be realized, as stipulated in Law no. 20 in the Year of 2003, article 3, shows that the goal of national education is to develop the potential of learners to become human beings who believe in one God the Almighty, have a noble character, become healthy, knowledgeable, skillful, creative, independent, and democratic and responsible citizens.

The Law no. 20 in the year of 2003 on the national education system reveals that the character of the Indonesian nation is based on five principles (pancasila) as follows: (1) Belief in the one and only God, (2) just and civilized humanity, (3) Unity of Indonesia, (4) Democracy led by the wisdom of the representatives of the People, and (5) Social justice for all Indonesians .

TABLE 1. IDENTIFYING THE SOURCE OF INDONESIAN CHARACTER

\begin{tabular}{|l|l|l|}
\hline No. & Five Principle Of Pancasila & \multicolumn{1}{|c|}{$\begin{array}{c}\text { Character Law } \\
\text { no. 20 Year 2003 }\end{array}$} \\
\hline 1 & $\begin{array}{l}\text { Belief In The One And Only } \\
\text { God }\end{array}$ & $\begin{array}{l}\text { Believe And Be Pious } \\
\text { In One God And Only }\end{array}$ \\
\hline 2 & Just And Civilized Humanity & Noble Character \\
\hline 3 & Unity Of Indonesia & $\begin{array}{l}\text { Healthy, Skilful, And } \\
\text { Independent }\end{array}$ \\
\hline 4 & $\begin{array}{l}\text { Democracy Led By The } \\
\text { Wisdom Of The } \\
\text { Representatives Of The People }\end{array}$ & $\begin{array}{l}\text { Knowledgeable, } \\
\text { Creative And } \\
\text { And Responsible }\end{array}$ \\
\hline 5 & $\begin{array}{l}\text { Social Justice For } \\
\text { All Indonesians }\end{array}$ & Democratic \\
\hline
\end{tabular}

\section{CHARACTER EDUCATION OF INDONESIAN NATION}

Inculcating character education is an effort to foster students' morals and attitude based on the norms and values of God, the almighty [7]. Character education is systematically designed and implemented to help students understand the values of human behavior based on God Almighty, self, other human beings, environment, and nationality represented in the thoughts, attitudes, feelings, words, and action based on religious norms, laws, manners, culture, and customs [5] .Character education is a system of inculcating the character values to school citizens including the components of knowledge, awareness, and actions to carry out those values, toward God Almighty (YME), self, other human being, environment, and nationality to become the complete human being [1]. The character education of Indonesian people is the conscious and deliberate effort to form the character or personality of a person based on the values in Indonesia 
society [4]. Those values come from Religion, Pancasila, cultures, goal of National Education.

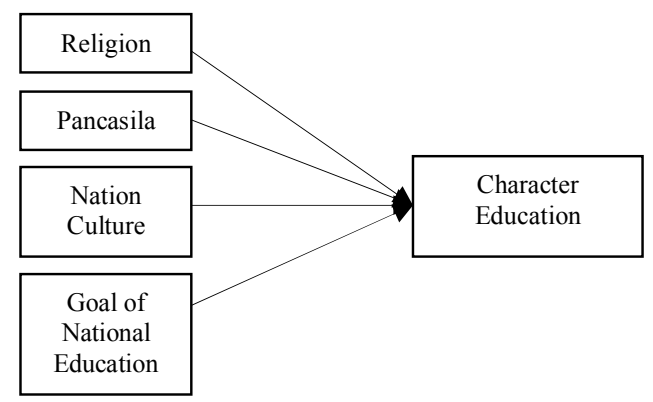

Chart I. Sources of Character Education of Indonesian People

Religion is the major source of character education of Indonesian nation because almost of people are religious community, so that character education must be based on values and religious norms. Pancasila, the national ideology of Indonesia, must be implemented in the life of nation and the state. Thus, character education should be based on the values of Pancasila. Culture is a truth where there is no any human being lives in a society without constituted by cultural values. Indonesian society is a society that has a wide range of culture, and thus, character education should be derived from the values of Indonesian nation's Culture. The goal of National educational includes various grades of humanity owned by a citizen. Therefore, the character education of Indonesian people is based on the goal of national education [2].

\section{PHILOSOPHY OF PANCASILA AS BASIS OF NATION'S EDUCATION CHARACTER}

Etymologically, the word "Pancasila" is derived from Sanskrit, Indian (the language of the Brahmin caste). According to Prof. Muhammad Yamin, in Sanskrit the word "Pancasila" has two kinds of meaning, namely: Panca means 'five', whereas, syiila deals with the rules of good or important attitude. Thus, Pancasila has moral and ethical principles [3]. Moral principles and ethics in Pancasila can be seen in Table II, as follows:

TABLE 2. MORAL AND ETHICS OF PANCASILA [3]

\begin{tabular}{|c|c|c|}
\hline NO & $\begin{array}{c}\text { five principle of } \\
\text { pancasila }\end{array}$ & Moral Principles and Pancasila ethics \\
\hline 1 & $\begin{array}{l}\text { Belief in the one } \\
\text { and only God }\end{array}$ & $\begin{array}{l}\text { - The Indonesian nations proclaim } \\
\text { their belief and devotion to God } \\
\text { Almighty. } \\
\text { - Indonesian nations trust towards God } \\
\text { Almighty based on religion and } \\
\text { beliefs that is just and civilized. } \\
\text { - Develop a respectful attitude and } \\
\text { collaborate with other different } \\
\text { religion believer toward God } \\
\text { Almighty. } \\
\text { Foster the harmony of life among } \\
\text { believers and the belief in God } \\
\text { Almighty } \\
\text { Religion and belief in God Almighty } \\
\text { is a matter of concerning the personal } \\
\text { relationship of man with God }\end{array}$ \\
\hline
\end{tabular}

TABLE 2, CONT.

\begin{tabular}{|c|c|c|}
\hline NO & $\begin{array}{c}\text { five principle of } \\
\text { pancasila }\end{array}$ & Moral Principles and Pancasila ethics \\
\hline & & $\begin{array}{l}\text { Almighty. } \\
\text { Develop mutual respect for freedom } \\
\text { of worship in accordance with their } \\
\text { religions and beliefs } \\
\text { - Not to impose a religion and belief } \\
\text { on God Almighty to others. }\end{array}$ \\
\hline 2 & $\begin{array}{l}\text { Just and civilized } \\
\text { humanity }\end{array}$ & $\begin{array}{l}\text { - Acknowledge and treat people } \\
\text { according to their prestige and } \\
\text { dignity as creatures of God } \\
\text { Almighty. } \\
\text { - Recognize the equality, equality of } \\
\text { rights and basic obligations of every } \\
\text { human being, without discrimination } \\
\text { their race, heredity, religion, belief, } \\
\text { gender, social status, color of skin } \\
\text { and so on. } \\
\text { - Develop a loving attitude among } \\
\text { human beings. } \\
\text { - Develop an attitude of mutual } \\
\text { tolerance and tolerance. } \\
\text { - Develop a non-arbitrary attitude } \\
\text { toward others. } \\
\text { - Uphold the values of humanity. } \\
\text { - Love to do humanitarian activities. } \\
\text { - Dare to defend truth and justice. } \\
\text { - The Indonesian nation feels himself } \\
\text { as a part of all humanity. } \\
\text { - Develop a respectful attitude and } \\
\text { cooperation with other nations. }\end{array}$ \\
\hline 3 & $\begin{array}{l}\text { The unity of } \\
\text { Indonesia }\end{array}$ & $\begin{array}{l}\text { - Able to place unity, and the interests, } \\
\text { and security of the nation and state as } \\
\text { a common interest over personal and } \\
\text { group interests. } \\
\text { - Able and willing to sacrifice for the } \\
\text { benefit of the state and nation if } \\
\text { necessary. } \\
\text { - Develop a sense of belonging to the } \\
\text { homeland and nation. } \\
\text { - Develop a sense of pride to the } \\
\text { homeland and nation. } \\
\text { Maintain world order based on } \\
\text { freedom, eternal peace and social } \\
\text { justice. } \\
\text { Develop Indonesian unity on the } \\
\text { basis of Bhinneka Tunggal Ika. } \\
\text { Promote association for the unity and } \\
\text { unity of the nation. }\end{array}$ \\
\hline 4 & $\begin{array}{l}\text { Democracy Led } \\
\text { By The Wisdom } \\
\text { Of The } \\
\text { Representatives } \\
\text { Of The People }\end{array}$ & $\begin{array}{l}\text { - As nations and citizens, every } \\
\text { Indonesian person has the same } \\
\text { position, rights and obligations. } \\
\text { - Not allowed to impose willing to } \\
\text { others. } \\
\text { - Prioritize deliberation in making } \\
\text { decisions for the common interest. } \\
\text { - Deliberation to reach consensus is } \\
\text { overwhelmed by the spirit of kinship. } \\
\text { - Respect and uphold any decisions } \\
\text { made as a result of deliberation. } \\
\text { - Having a good intentions and a sense } \\
\text { of responsibility to accept and } \\
\text { implement the results of the } \\
\text { deliberation. } \\
\text { In the deliberations is prioritized the } \\
\text { common interest above the private } \\
\text { and group interests. } \\
\text { Deliberation is implemented by } \\
\text { common sense based on a noble } \\
\text { conscience. }\end{array}$ \\
\hline
\end{tabular}




\begin{tabular}{|c|c|c|}
\hline NO & $\begin{array}{l}\text { five principle of } \\
\text { pancasila }\end{array}$ & Moral Principles and Pancasila ethics \\
\hline & & $\begin{array}{l}\text { - The decisions made must be morally } \\
\text { accountable to God Almighty, } \\
\text { uphold the dignity of human beings, } \\
\text { the values of truth and justice that } \\
\text { prioritize unity and unity for the } \\
\text { common interest. } \\
\text { - Trust to representatives to carry out } \\
\text { deliberations. }\end{array}$ \\
\hline 5 & $\begin{array}{l}\text { Social } \\
\text { Justice For } \\
\text { All Indonesians }\end{array}$ & 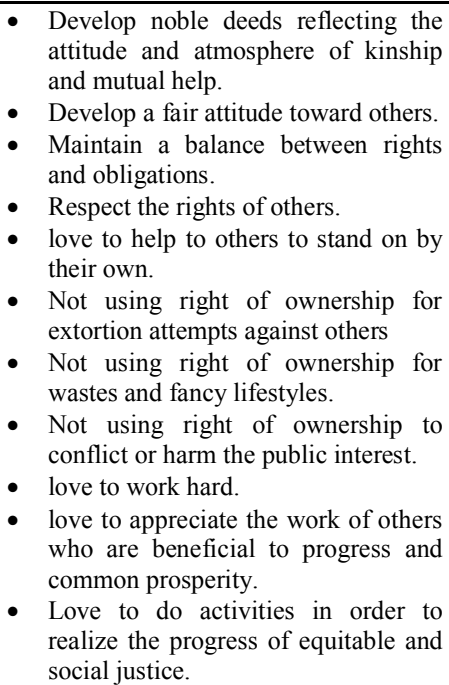 \\
\hline
\end{tabular}

Pancasila is generally meant as world view (way of life), view of life (Weltanschauung), a lifeline (weldbeschauung), hints of life (wereld en levens beschouwing). In this case, Pancasila is intended as a guide of life that must be practiced in everyday life [3]. In other words, Pancasila is s guide of all activities and life and living in all areas: in politics, education, religion, culture, social and economic. This means that all behavior and actions of Indonesian nations must be inspired and based on Pancasila [6].

\section{RECOMMENDATIONS FOR CHARACTER EDUCATION OF INDONESIAN NATION}

The character education of Indonesia nation is needed to be reconstructed because Panca sila as the basis of character education has the same status as character education such as Religion, Culture, and goal of National Education. Pancasila as ideology of the nation is defined as the overall views, ideals, and beliefs of Indonesia on the history, society, law and the state of Indonesia as a result of crystallization of the values that already exist in Indonesia country referred from customs, culture, religion, and belief in God Almighty. Pancasila as an ideology found from the spiritual, moral, and cultural wealth of Indonesian society and comes from the nation's life view. Thus, the ideology of Pancasila belongs to all the people and the nation of Indonesia. Therefore, Indonesia people are obliged to realize the ideology of Pancasila in life of society, nation and the state, or based on the values of Pancasila. Character education is one effort to inculcate the values of Pancasila in the life of Indonesian society. Therefore, character education should be based on the values of Pancasila as a whole, not other sources, such as Religion, Culture, and goal of national education. . in this case because Religion, Culture and goal of National educationare part of Pancasila.

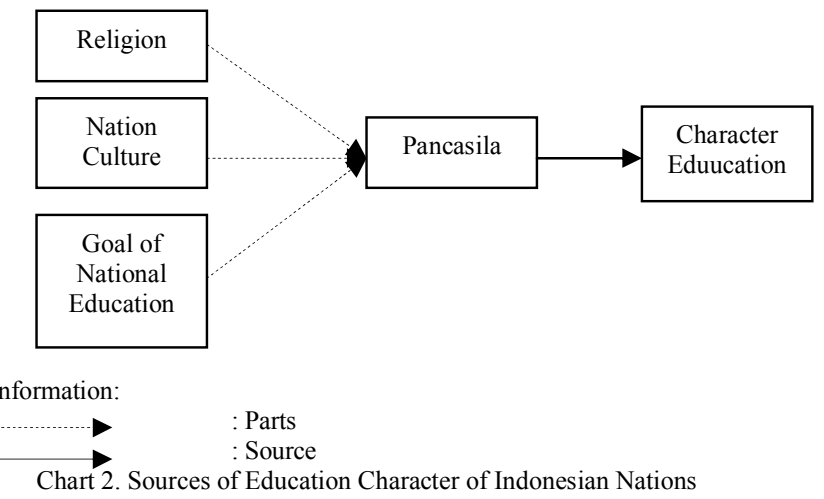

\section{CONCLUSION}

Character education is an attempt to build the character of the Indonesian nation based on the values of Pancasila. Therefore, nation's character education must be built based on Pancasila, not other sources such as Religion, Culture, and goal of National Education because Religion, Culture and goal of National education are part of Pancasila.

\section{ACKNOWLEDGMENT}

Thanks to Universitas Muhammadiyah Sidoarjo for funded this research.

\section{REFERENCES}

[1] Citra Yulia. Pelaksanaan Pendidikan Karakter dalam Pembelajaran. EJUPEKhu (Jurnal Ilmiah Pendidikan Khusus) Volume 1 Nomor 1, p.238, Januari 2012. http://ejournal.unp.ac.id: diakses tanggal 24 Juni 2017

[2] Hasan, SH dkk. Pengembangan Pendidikan Budaya dan Karakter Bangsa. Puskur: Jakarta, p.7, , 2010.

[3] Kaelan. (1993). Pendidikan Pancasila Yuridis Kenegaraan. Yogyakarta: Paradigma, p.18, p.67, p. 187-189,1993.

[4] Kurniawan, MI. Tri Pusat Pendidikan Sebagai Sarana Pendidikan Karakter Anak Sekolah Dasar. Journal Pedagogia ISSN 2089 -3833 Volume. 4, No. 1, p.42, Februari 2015: http://ojs.umsida.ac.id:diakses tanggal 23 Juni 2017

[5] Pranowo, Dj. Implementasi Pendidikan Karakter Kepedulian dan Kerjasama Pada Matakuliah Keterampilan Berbicara Bahasa Prancis dengan Metode Bermain Peran. P.4, 2013: http://journal.uny.ac.id: diakses tanggal 24 Juni 2017

[6] Kirom Syahrul. Filsafat Ilmu dan Arah Pengembangan Pancasila: Relevansinya dalam Mengatasi Persoalan Kebangsaan. Jurnal Filsafat Vol.21, Nomor 2: UGM, p.105, 2011.

[7] Zulnuraini. (2012). Pendidikan Karakter: Konsep, Implementasi Dan Pengembangannya di Sekolah Dasar di Kota Palu, 2011 http://pgsduntad.com: diakses tanggal 24 Juni 2017 